Kabul Tarihi: 06.06.2017

\title{
Halka Açık Konaklama İşletmelerinin Nakit Akış Profillerinin Analizi: Uluslararası Bir Karşılaştırma
}

\section{Analyzing the Cash Flow Profiles of Publicly Held Lodging Companies: An International Comparison}

\author{
Doç. Dr. Erdinç KARADENiz \\ Mersin Üniversitesi \\ Turizm Fakültesi \\ E-posta: drkaradeniz@gmail.com \\ Orcid Id: 0000-0003-2658-8490
}

Öz

$\mathrm{Bu}$ çalışmanın temel amacı halka açık konaklama işletmelerinin nakit akış performanslarının "Nakit Akışlarının Sağlandığı Faaliyetler Yöntemine" göre uluslararası olarak karşılaştırmalı analiz edilmesidir. Bu kapsamda Amerika kıtasında yer alan 25, Avrupa kıtasında yer alan 51 ve Asya-Pasifik kıtasında yer alan 131 olmak üzere toplamda 207 konaklama şirketi analize dahil edilmiştir. Söz konusu konaklama işletmelerinin 2013-2014-2015 yıllarına ait nakit akış tabloları "Nakit Akışlarının Sağlandığı Faaliyetler Yöntemine" göre incelenmiştir. Bu inceleme yıl, kıta ve Türkiye temelinde gerçekleştirilmiştir. Bu kapsamda yıllık 621, analiz süresince de 1863 gözlem gerçekleştirilmiştir. Araştırma sonuçlarına göre incelenen konaklama işletmelerinin yıl, kıta ve Türkiye temelinde Model 2: başarılı işletme, Model 4: büyüyen işletme ve Model 3: gerileyen veya yeniden yapılanan işletme profillerinde yoğunlaştığı belirlenmiştir.

Anahtar Kelimeler: Nakit akış tablosu, Nakit akışlarının sağlandığı faaliyetler yöntemi, Nakit akış profili, Halka açık konaklama işletmeleri.

\begin{abstract}
The aim of this study is to conduct a comparative international analysis of the cash flow performance of publicly held lodging companies according to "Cash Flow Patterns Method". In this context, a total of 207 publicly held lodging companies, including 25 in the America region, 51 in Europe region, and 131 in the Asia-Pacific region, were included in the analysis. The cash flow statements of the mentioned lodging companies for the years 2013-2014-2015 have been examined according to the "Cash Flow Patterns Method". In this context, 621 observations per year were made and 1863 observations during the analysis period. The analysis has been done by the year, region, and Turkey. According to the results of the research based on year, region and Turkey, cash patterns of the publicly held lodging companies were found as; Model 2: successful company, Model4: growing company and Model 3: regressing or restructuring company.
\end{abstract}

Keywords: Cash flow statement, Cash flow patterns method, Cash flow profile, Publicly held lodging companies. 


\section{Giriş}

1950'li yıllardan sonra işletme değerinin ortakları açısından maksimum kılınması olgusu kar maksimizasyonu olgusunun önüne geçmesine rağmen günümüzde işletme yöneticilerinin zaman zaman kar maksimizasyonuna yönelik karar almaları neticesinde kısa vadeli başarılar elde edilse de uzun vadede işletmelerin sürdürebilirliği açısından sorunlar yaşanabilmektedir. Özellikle bir işletmede, değeri belirleyen değişkenler olan nakit akışı, zamanlama ve risk faktörlerine daha fazla dikkat edilmesi gerekliliği önem kazanmaktadır. Ancak bazı işletme yöneticilerinin net kar ile nakit akışının aynı şey olduğuna yönelik algıları, diğer bir ifadeyle işletmenin elde ettiği net kar tutarı ne ise o kadar nakit akışına ve nakit düzeyine sahip olacaklarına inanmaları yukarıda bahsedilmeye çalışılan sorunlara yol açabilmektedir. Kar ve nakit akışı, işletmeler açısından önemli performans göstergeleridir. Ancak kar ile nakit akışı aynı kavram değildir. Bir işletme yüksek bir net kara sahip olabilir ancak nakit akışı düzenli ve sağlıklı olmayabilir. Nakit akışlarının düzenli ve sağlıklı olmaması da işletmenin vadesi gelen yükümlülüklerini yerine getirememesine ve faaliyetlerine devam edememesine neden olabilir ve bu durum yüksek bir net kara sahip olsa da işletmeyi iflasa sürükleyebilir. Bu bağlamda özellikle işletmelerin esas işletme faaliyetlerinden nakit akışı yaratması büyük önem arz etmektedir. Dolayısıyla kar, nakit ve nakit akışı kavramlarının ne olduğunun işletme yöneticilerince iyi anlaşılması gerekmektedir (Elmas, 2015; Karğın ve Aktaş, 2011).

İşletme biliminde kar genel olarak gelir ile maliyet arasındaki olumlu fark olarak kabul edilmektedir. Nakit ise bir işletmenin faaliyetlerini sürdürürken ihtiyaç duyduğu varlığı ifade etmektedir. 2014 yılında yayımlanan "TMS 7 Nakit Akış Tabloları Yönetmeliği”, işletmedeki nakit ile vadesiz mevduatı nakit olarak tanımlarken, tutarı belirli bir nakde kolayca çevrilebilen kısa vadeli ve yüksek likiditeye sahip ve değerindeki değişim riski önemsiz olan yatırımları nakit benzeri olarak tanımlamaktadır. Nakit akışı ise nakit ve nakit benzerlerinin giriş ve çıkışları olarak tanımlanmaktadır (Uyar, 2015; Elmas, 2015).

Turizm sektöründe faaliyet gösteren konaklama işletmeleri, yatırım aşamasında sabit sermaye yoğun buna karşın işletme aşamasında ise emek yoğun ve işletme sermayesi ihtiyacı yüksek olan işletmelerdir. Bununla beraber turizm sektörünün kendine has özelliklerinden dolayı faaliyet riski yüksek olan, kontrol edilemeyen birçok politik-ekonomik-sosyal gelişmeler karşısında kırılgan ve talebin son derece esnek olduğu işletmelerdir. Yine bu işletmelerde faiz, kur ve likidite riskleri de yüksek olabilmektedir. Haftanın yedi günü ve yirmi dört saat hizmetin devam ettiği bu işletmelerde yerine getirilen yatırım, işletme ve finansman faaliyetlerinden dolayı nakit giriş ve çıkışları hızlı bir şekilde gerçekleşebilmektedir. Dolayısıyla nakit akışlarının mevcut durumda analiz edilmesi, miktar ve zaman açısından planlanması ve kontrol edilmesi, konaklama işletmelerinde günlük faaliyetlerin yerine getirilebilmesi, yükümlülüklerin karşılanması, beklenmedik durumlar karşısında hazırlıklı olunması ve değer maksimizasyonu açısından son derece önemlidir.

$\mathrm{Bu}$ çalışmada halka açık konaklama işletmelerinin nakit akış profilleri "Nakit Akışlarının Sağlandığı Faaliyetler Yöntemine" göre uluslararası olarak karşılaştırmalı analiz edilmesi amaçlanmaktadır. Bu bağlamda Amerika, Avrupa ve Asya-Pasifik kıtalarında yer alan ülke borsalarında işlem gören toplamda 207 konaklama şirketinin 2013-2015 yılları arasındaki nakit akışları karşılaştırmalı olarak analiz edilmiştir. Çalışma, belirlenen amaçlar doğrultusunda beş temel bölümden oluşmaktadır. Birinci bölümde nakit akış tablosu ve nakit akışlarının analizinde kullanılan nakit akışlarının sağlandığı faaliyetler yöntemi hakkında bilgiler verilmektedir. İkinci bölümde konuyla 
ilgili literatür taramasının sonuçları sunulmaktadır. Üçüncü bölümde çalışmada kullanılan veri ve yöntem açıklanmaktadır. Dördüncü bölümde analiz sonucunda elde edilen bulgular tartışılmaktadır. Sonuç bölümünde ise genel bir değerlendirme yapılarak konaklama işletmelerine yönelik sektörel öneriler ile gelecekte konuyla ilgili yapılacak araştırmalar için öneriler sunulmaya çalışılmaktadır.

\section{Nakit Akış Tablosu Ve Nakit Akışlarının Sağlandığı Faaliyetler Yöntemiyle Analizi}

"Nakit akış tablosu, işletmelerde bir faaliyet dönemi içerisinde meydana gelen nakit akışlarını işletme faaliyetlerine, yatııı faaliyetlerine ve finansman faaliyetlerine ilişkin nakit akışları olarak gösteren tablodur" (Şamiloğlu ve Akgün, 2015: 156). Diğer bir ifadeyle nakit akış tablosu, belirli bir faaliyet döneminde hangi faaliyetlerden ne kadar nakit sağlandığını ve hangi faaliyetlere ne kadar nakit harcandığını ortaya koymaktadır. Bu bağlamda nakit akım tablosu, fon akım tabloları içerisinde fonu en dar anlamı olan nakit olgusu ile ele almaktadır. Nakit giriş ve çıkışına neden olmayan gider, gelir veya iktisadi olaylar bu tabloda yer almaz. Dolayısıyla "nakit akış tablosu işletmenin nakit yönetimini ve politikasını açıklamaktadır" (Toroslu ve Durmuş, 2016: 81). Nakit akış tablosu nakit esasına göre hazırlandığından dolayı işletmeye kredi verenler, yatırımcılar, yöneticiler ve işletmeyle ilişkili diğer kesimler tarafından işletmenin gelecekteki nakit akışları değerlendirilirken yararlanılır. Nakit akış tablosuyla, diğer finansal tablolarla birlikte işletmenin net varlıklarındaki değişimi, gerçek likiditesini, borç ödeme gücünü, finansal performansını ve nakit akışlarının tutar ve zamanlamasını değişkenlik gösteren iktisadi şartlara ve fırsatlara uyum sağlamak amacıyla etkileme yeteneği tespit edilmeye çalışılmaktadır (Elmas, 2015; TMS 7, 2016, m. 4).

Türkiye Muhasebe Standartları (TMS) 7'ye göre bir faaliyet dönemine ilişkin nakit akışları dolaylı yöntem ve dolaysız yöntem olmak üzere iki yöntemle raporlanabilir. Dolaylı yöntemde işletme faaliyetlerinden sağlanan nakit akışları, net kar veya zararının stoklar ile alacak ve borçlardaki değişiklik, amortisman, vergi ve faiz gibi nakit girişi ve çıkışı etkileri olan işlemlerde düzeltmeler yapılmaktadır. Son olarak yatırım veya finansman faaliyetlerinden oluşan nakit akışları dikkate alınarak tablo oluşturulur.

Dolaysız yöntemde ise brüt nakit girişleri ve brüt nakit çıkışlarına ait ana gruplar belirtilir. Bu yöntemde nakit akışı tablosu muhasebe kayıtlarından, satışlar ve satışların maliyeti bilgilerinden, stoklar ve alacaklar gibi nakit etkisi olan tüm kalemlerle ilgili detaylı incelemeyle oluşturulur. Bu nedenle dolaysız yöntem, nakit akışlarının tahmin edilmesinde daha ayrıntılı bilgiler sağlamaktadır. Türkiye'de uygulama birliğinin sağlanması amacıyla Türkiye Muhasebe Standartları Kurulu tarafından dolaysız yöntem önerilmiş ve Tablo 1'deki şekliyle nakit akış tablosunun hazırlanması tercih edilmiştir (Kargın ve Aktaş, 2011). TMS 7 nakit akış tablosu standardında, bir nakit akış tablosunda döneme ilişkin nakit akışlarının işletme, yatırım ve finansman faaliyetlerine dayalı bir biçimde sınıflandırılarak raporlanması gerekliliğine vurgu yapılmaktadır. Bir işletme, yatırım ve finansman faaliyetlerinden olan nakit akışlarını iş sahasına en uygun şekilde gösterir. Faaliyet temelli sınıflama, kullanıcılara, bu faaliyetlerin işletmenin finansal durumu ile birlikte nakit ve nakit benzerlerine olan etkisine ilişkin bilgi sağlar. Bu bilgi ayrıca, faaliyetler arasındaki ilişkilerin değerlendirilmesi için de kullanılabilir (TMS 7, 2016, m.11). 


\section{Tablo 1: Nakit Akış Tablosu (Dolaysız Yöntem)}

\section{A. IŞLETME FAALIYETLERINE ILIŞKIN NAKIT AKIŞLARI}

Cari Önceki Dönem Dönem

1.Esas Faaliyet Gelirlerinden Sağlanan Nakit Girişleri (+)

a) Satışlardan sağlanan nakit girişleri $(+)$

b) Gelirlerden sağlanan nakit girişleri(+)

2 Esas Faaliyet Giderlerine İlişkin Nakit Çıkışları** (-)

a) Satılan mal ve hizmet maliyetleri ve stok değişimlerine ilişkin nakit çıkışları(+)

b) Faaliyet Giderlerine İlişkin Nakit Çıkışları (+)

\section{Esas Faaliyet Sonucu Sağlanan Net Nakit Akışı(1-2)}

3. Diğer Gelir ve Karlardan Sağlanan Nakit Girişleri +

4. Diğer Gider ve Zararlardan Kaynaklanan Nakit Çıkışları(-)

5.Finansman Giderlerinden Kaynaklanan Nakit Çıkışları (-)

6. İşletme Faaliyetleriyle İlgili Varlık ve Yabancı Kaynaklardaki

Değişikliklere İlişkin Nakit Akışları (+) (-)

a) Varlık Artışları (-)

b) Varlık Azalışları (+)

c) Yabancı Kaynak Artışları (+)

d) Yabancı Kaynak Azalışları (-)

7. Dönem Karı Vergi ve Diğer Yasal Yükümlülüklere İlişkin Nakit Çıkışları (-)

a) Önceki Dönem Karından Ödenen (+)

b) Geçici Vergiler(+)

\section{B. YATIRIM FAALIYETLERINE ILIŞKIN NAKIT AKIŞLARI}

1.Yatırım Faaliyetinden Sağlanan Nakit Girişleri(+)

2. Yatırım Faaliyetlerine İlişkin Nakit Çıkışları (-)

\section{FINANSMAN FAALIYETLERINE İLIŞKIN NAKIT AKIŞLARI}

1. Finansman Faaliyetlerinden Sağlanan Nakit Girişleri

2. Finansman Faaliyetlerine İlişkin Nakit Çıkışları (-)

D. KUR FARKLARININ NAKIT VE NAKIT BENZERLERINE ETKILERI (+), (-)

E. NAKIT VE NAKIT BENZERLERINDE MEYDANA GELEN NET ARTIŞ (+) (AZALIŞ) (-)

F. DÖNEM BAŞI NAKIT VE

NAKIT BENZERLERI MEVCUDU

G. DÖNEM SONU NAKIT VE NAKIT BENZERLERI MEVCUDU

Kaynak: TMS 7, (2016).

Bu kapsamda nakit akış tablolarında, belirli bir faaliyet döneminde meydana gelen nakit akışlarını; işletme faaliyetlerinden, finansman faaliyetlerinden ve yatırım faaliyetlerinden kaynaklanan nakit akışları başlıkları altında sunulmaktadır. Söz konusu faaliyet alanlarına ait nakit akışları aşağıda açıklanmaya çalışıımaktadır.

\section{1. İşletme Faaliyetlerinden Kaynaklanan Nakit Akışları}

İşletme faaliyetleri, genellikle işletmenin esas faaliyetleri ile yatırım ve finansman faaliyeti olmayan diğer faaliyetleridir (Uyar, 2015:43). İşletme faaliyetlerinden kaynaklanan nakit akışları ise işletmenin esas faaliyetleriyle ilgili olup, net karın veya 
zararın belirlenmesinde yer alan işlem ve faaliyetlerden kaynaklanır. İşletme faaliyetlerinden kaynaklanan nakit akışları, dış finansman kaynaklarına ihtiyaç duyulmadan işletmenin; borçlarını geri ödeyebilmesi, faaliyetlerini sürdürebilmesi, kar payı ödemelerini yapabilmesi ve yeni yatırımlara başlayabilmesinin mümkün olup olmadığı hususlarında temel bir gösterge teşkil etmek üzere sunulmaktadır (TMS 7, 2016, m.13). İşletme faaliyetlerinden kaynaklanan nakit akışları, işletme açısından uzun vadede fonların ana kaynağını temsil ettiğinden, nakit akış tablosunun en önemli unsurunu oluşturmaktadır. Genel olarak işletmelerin, işletme faaliyetlerinden elde ettikleri nakit akışlarının pozitif olması istenir. Buna karşın birbirini izleyen faaliyet dönemleri itibarıyla İşletme faaliyetlerinden kaynaklanan nakit akışları negatif ise, işletmenin başka kaynaklardan (örneğin yeni borçlanma ya da hisse senedi ihracı yoluyla) nakit elde etmesi gerekecektir. Ancak, işletme faaliyetlerinden kaynaklanan nakit akışları uzun süre negatif olursa yatırımcıların işletmeye olan güveni kaybolacaktır (Orhan ve Başar, 2015). TMS 7, 14. maddesinde işletme faaliyetlerinden kaynaklanan nakit akışlarına ait örnekleri aşağıdaki gibi sıralamaktadır;

- Satılan mallardan ve verilen hizmetlerden (satışlardan) elde edilen nakit girişleri,

- Royalti, ücret, komisyon ve diğer hasılatla ilgili nakit girişleri,

- Mal ve hizmetler için yapılan ödemelerden kaynaklanan nakit çıkışları,

- Çalışanlara ve çalışanlar adına yapılan ödemelerden kaynaklanan nakit çıkışları,

- Sigorta şirketlerinin aldığı veya ödediği primler, tazminatlar, yıllık ödemeler ve poliçeyle ilgili diğer yükümlülükler nedeniyle oluşan nakit giriş ve çıkışları,

- Finansman veya yatırım faaliyeti ile doğrudan ilgili olmadığı sürece kurum kazancı üzerinden hesaplanan diğer vergilerle ilgili nakit çıkışları veya söz konusu vergiler kapsamında alınan vergi iadeleri ile ilgili nakit girişleri,

- Alım satım amaçlı elde bulundurulan sözleşmelerle ilgili nakit girişleri ve çıkışları.

\subsection{Yatırım Faaliyetlerinden Kaynaklanan Nakit Akışları}

Yatırım faaliyetleri, bir işletmede uzun vadeli varlıkların ve nakit benzeri içinde yer almayan diğer yatırımların elde edilmesi veya elden çıkarılmasına yönelik gerçekleştirilen faaliyetler olarak tanımlanmaktadır (Elmas, 2015). Diğer bir ifadeyle işletmede taşınmaz, tesis ve teçhizat için yapılan ödemeler ya da yeni işletme birleşmeleri, bir işletmenin kendi geleceğine yönelik yatırımını ifade etmektedir ve işletmenin nakit çıkışlarının büyük çoğunluğu bu alanda olmaktadır. Bu nedenle işletmelerin genellikle yatırım faaliyetinden kaynaklanan nakit akışlarının negatif olması beklenir. Çünkü böyle bir durumda yeni büyüme fırsatlarına yatırım yaptıkları ve/veya mevcut duran varlıklarını yeniledikleri söylenebilir (Orhan ve Başar, 2015). Bu kapsamda yatırım faaliyetlerinden kaynaklanan nakit akışlarının ayrı olarak gösterilmesi, gelecekte işletmeye gelir ve nakit akışı sağlaması öngörülen kaynaklar için yapılan harcamaların düzeyinin ifade edilmesi açısından önem arz etmektedir. TMS 7, 16. maddesinde yatırım faaliyetlerinden kaynaklanan nakit akışlarına ait örnekleri aşağıdaki gibi sıralamaktadır;

- Maddi ve maddi olmayan duran varlıklar ve diğer uzun vadeli varlıkların alımı veya satımı ile ilgili nakit çıkış veya nakit girişleri,

- Nakit benzeri veya alım satım amacıyla elde tutulan araçlarla ilgili olmadığı sürece, başka bir işletmeye iştirak etmek veya o işletmenin borçlanma aracını satın almak için ve müşterek yönetime tabi iş ortaklığına katılmak için yapılan nakit çıkışları,

- Nakit benzeri veya alım satım amacıyla elde tutulan araçlarla ilgili olmadığı sürece, başka bir işletmenin hisse senedinin veya borçlanma aracının veya işletmenin bir müşterek yönetime tabi iş ortaklıklarındaki payının satılması sonucu elde edilen nakit girişleri, 
- Finansal kurumların yaptıkları işlemler hariç olmak üzere, işletmeler tarafından üçüncü kişilere verilen avans ve borçlara ilişkin nakit çıkışları,

- Finansal kurumların yaptıkları işlemler hariç olmak üzere, işletmelerin üçüncü kişilere verdikleri avans, kredilerden yapılan tahsilâtlara ilişkin nakit girişleri,

- Alım satım amacıyla yapılanlar ve finansman faaliyetleriyle ilgili olanlar hariç, vadeli işlem veya forward sözleşmesi, opsiyon sözleşmeleri ve swap sözleşmelerine ilişkin nakit giriş ve çıkışları.

\subsection{Finansman Faaliyetlerinden Kaynaklanan Nakit Akışları}

Finansman faaliyetleri, bir işletmenin öz kaynakları ile yabancı kaynaklarının yapısında ve tutarında değişiklik meydana getiren faaliyetler olarak tanımlanmaktadır. Finansman faaliyetlerinden kaynaklanan nakit akışları, borç geri ödemeleri, yeni borçlanmalar, işletmenin hisse senedi ihracı, kâr payı vb. finansal işlemler nedeniyle ortaya çıkar. Bu faaliyetlerden elde edilen nakit akışları işletmenin mevcut ve gelecekteki sahiplerinin işletmeye yaptığı yatıımı yansıtır. Finansman faaliyetlerinden kaynaklanan nakit akışları, işletmeye sermaye sağlayanların işletmenin gelecekteki nakit akışlarından talep edecekleri kısmın belirlenmesini sağlamak üzere ayrı olarak açıklanır (Orhan ve Başar, 2015; TMS 7, 2016, m. 6 ve m. 17). TMS 7, 17. maddesinde finansman faaliyetlerinden kaynaklanan nakit akışlarına ait örnekleri aşağıdaki gibi sıralamaktadır;

- Hisse senedi ve diğer öz sermaye araçlarının ihracından sağlanan nakit girişleri,

- Sermayenin azaltıması veya işletmenin kendi hisse senetlerini satın almasıyla ilgili nakit çıkışları,

- Borçlanma araçları ihracı ve diğer uzun ve kısa vadeli krediler ile sağlanan nakit girişleri,

- Borç ödemelerine ilişkin nakit çıkışları,

- Finansal kiralama sözleşmelerinden kaynaklanan borç ödemelerine ilişkin nakit çıkışları.

\section{Nakit Akış Tablosunun Nakit Akışlarının Sağlandığı Faaliyetler Yöntemi İle Analizi}

İşletmelerin faaliyetlerinden nakit yaratma yeteneği onun faaliyetlerini sürdürebilmesi ve büyüyebilmesi için önemli bir göstergedir. Normal şartlarda ve varsayımlarda işletme faaliyetlerinden sağlanan nakit akışının pozitif, yatırımlar ve finansman faaliyetleri ile ilgili nakit akışlarının negatif olması gerekir. Bu durumdaki işletmelerin esas faaliyetleri ile yatırımlarını ve finansman faaliyetlerini destekleyebildiği kabul edilmektedir (Orhan ve Başar, 2015).

Nakit akış tabloları, diğer finansal tablolarda olduğu gibi yatay analiz, trend analizi ve oran analizi yöntemleri uygulanarak incelenebilir. Bu yöntemler haricinde nakit akışlarının sağlandığı faaliyetler yöntemiyle de işletmelerin nakit akış profilleri analiz edilebilmektedir (Aktaş ve diğ., 2012).

Nakit akışlarının sağlandığı faaliyetler yöntemi ilk defa Gup ve diğ. (1993) tarafından geliştirilmiş bir yöntemdir. Gup ve diğ. (1993), nakit akışlarının hangi faaliyetlerden elde edildiğini ve bu nakit akışlarının nerelerde kullanıldığının belirlenmesinin önemini vurgulamışlardır. $\mathrm{Bu}$ bağlamda işletmelerin nakit akış tablolarında yer alan faaliyetlere göre nakit akışlarının büyüklüğünü dikkate almadan, durumunu (negatif veya pozitif) incelemişler ve belirli nakit akış özelliklerine göre farklı işletme profilleri oluşturmuşlardır. 
Nakit akışlarının sağlandığı faaliyetler yöntemine göre, bir nakit akış tablosunda nakitlerin izlediği sekiz temel farklı profil bulunmaktadır (Gup ve diğ.,1993). Nakit akışlarının sağlandığı faaliyetler yönteminin ileri sürdüğü sekiz profilin her birini model olarak değerlendirmek mümkündür. İşletmenin her bir finansal özelliği bir modele dahil edilmekte ve buradaki analiz ile nakit akış tablosunun işlevlerinin daha iyi anlaşılabilmesi ya da daha farklı bilgilerin edinilmesi sağlanabilmektedir. Bu yöntem biraz basit algılansa bile, yapılan analiz ilgili işletmenin nakit akış tablosu hakkında bilgi sağlamaktadır (Kargın ve Aktaş 2011).

Nakit akışlarının sağlandığı faaliyetler yönteminin belirlediği sekiz nakit akış modeli Tablo 2'de sunulmaktadır.

Tablo 2: Nakit Akışlarının Sağlandığı Faaliyetler Yönteminde Nakit Akış Modelleri

\begin{tabular}{|c|c|c|c|c|}
\hline Modeller & İşletme Profilleri & $\begin{array}{c}\text { iş̧letme } \\
\text { Faaliyetlerinden } \\
\text { Nakit Akışı }\end{array}$ & $\begin{array}{c}\text { Yatııım } \\
\text { Faaliyetlerinden } \\
\text { Nakit Akışı }\end{array}$ & $\begin{array}{c}\text { Finansman } \\
\text { Faaliyetlerinden } \\
\text { Nakit Akışı }\end{array}$ \\
\hline Model 1 & Nadir Durum & + & + & + \\
\hline Model 2 & Başarııı İ̧̧letme & + & - & - \\
\hline Model 3 & $\begin{array}{c}\text { Gerileyen veya } \\
\text { Yeniden Yapılanan } \\
\text { İşletme }\end{array}$ & + & + & - \\
\hline Model 4 & Büyüyen Iş̧letme & + & - & + \\
\hline Model 5 & Küçülen İşletme & - & + & + \\
\hline Model 6 & Genç Iş̧letme & - & - & - \\
\hline Model 7 & $\begin{array}{c}\text { Likiditasyona Giden } \\
\text { Işletme }\end{array}$ & - & + & - \\
\hline Model 8 & Nadir Durum & - & - & + \\
\hline
\end{tabular}

Kaynak: (Aktaş ve diğ., 2012:106; Karğın ve Aktaş, 2011:10).

Tablo 2'de yer alan modellerde yer alan işletme profillerinin özellikleri sırasıyla açıklanmaktadır (Aktaş ve diğ., 2012; Karğın ve Aktaş, 2011; Orhan ve Başar, 2015);

Model 1 (Nadir Durum): Bu modelde işletme; işletme, yatırım ve finansman faaliyetlerinden nakit girişi sağlamaktadır $(+,+,+)$. Bu modele göre işletme, nakit girişlerini esas faaliyetlerden, yatırımlar veya duran varlık satış gelirlerinden, borçlanma ya da öz sermaye artısından sağlamaktadır. Böyle bir profilin sık rastlanan bir durum olmadığı ve bu durumun geçici olduğu kabul edilmektedir. Diğer bir ifadeyle işletmenin gelecekte yüksek düzeyde bir nakit çıkışı için hazırlık yaptığı kabul edilmektedir. Bu tür nakit akışlarına sahip işletmelerin toplam varlıklarının düşük olduğu, negatif büyüme oranına sahip olduğu ve ortalama olarak karlı olmadıkları gözlemlenmektedir.

Model 2 (Başarılı İşletme): Bu modelde işletme; işletme faaliyetlerinden nakit girişi elde ederken, yatırım ve finansman faaliyetlerinden ise nakit çıkışına sahip olmaktadır $(+,-,-)$. Bu modele göre bu tarz nakit akışlarına sahip işletmelerin günlük faaliyetlerini fonlayabilmek için yeterli işletme faaliyeti nakit akışı yaratabilen ve borçlarını geri ödeyebilen sağlıklı bir yapıda oldukları ve dengeli, olgun ve başarılı bir finansal yönetime sahip oldukları kabul edilmektedir. Ayrıca bu profilin yaygın bir durum olduğu kabul edilmektedir. Bu tür nakit akışlarına sahip işletmelerin toplam varlıklarının çok büyük tutarlarda olduğu, karlılıklarının yüksek olduğu ve makul oranda büyüme gösterdikleri gözlemlenmektedir. 
Model 3 (Gerileyen veya Yeniden Yapılanan İşletme): Bu modelde işletme; faaliyet ve yatırım faaliyetlerinden nakit girişi elde ederken, finansman faaliyetlerinden nakit çıkışlarına sahiptir $(+,+,-)$. Bu modele göre işletmede ana faaliyetlerden ve duran varlık yatırımlarının satılması ile sağlanan nakit girişleri, borç ödemesi olarak ve hissedarlara yapılan ödemelerde kullanılmaktadır. Bu nedenle de duran varlıkların satışı zorunlu hale gelebilir. $\mathrm{Bu}$ işletmelerin ılımlı bir büyüme oranına sahip olduğu kabul edilmektedir. Bu modelinde nadir olduğu ileri sürülmektedir.

Model 4 (Büyüyen İşletme): Bu modelde işletme; faaliyet ve finansman faaliyetlerinden nakit girişi elde ederken, yatırım faaliyetlerinden nakit çıkışlarına sahiptir $(+,-,+)$. Bu modele göre işletmenin faaliyetlerinden sağladığı nakit akışlarının yatırım faaliyetlerini karşılamada yetersiz kaldığı ve bu nedenle işletmenin ya hisse senedi ihraç ettiği ya da yeni bir borçlanmaya gittiği kabul edilmektedir. İşletmeler sabit varlık yatırımları gerçekleştirerek gelirlerini artıımak durumundadırlar. Bu profilde söz konusu yatırımların özkaynak veya yabancı kaynaklar tarafından finanse edilmesi, yatırımcıların ve borç verenlerin işletmenin geleceğiyle ilgili iyimser bir algıya sahip olduklarını göstermektedir. Modelin ifade ettiği nakit akışlarına sahip işletmelerin büyüme stratejilerine yöneldiği düşünülmektedir.

Model 5 (Küçülen İşletme): Bu modelde işletme; işletme faaliyetlerinden nakit çıkışlarına sahipken, yatırım ve finansman faaliyetlerinden nakit girişi elde etmektedir ($,+,+)$. Modele göre işletmenin esas faaliyetlerinin nakit girişi sağlamadaki başarısızlığı, yatırım faaliyetlerinden vazgeçilerek ve borç ile öz sermaye yapısının arttırıması suretiyle karşılanmaya çalışılmaktadır. Duran varlıklardaki azalışlar, işletmenin büyüme fırsatının daraldığını ve işletmenin küçülme eğilimi içerisinde olduğunu gösterebilir.

Model 6 (Hızlı Büyüyen-Genç İşletme): Bu modelde işletme; esas işletme ve yatırım faaliyetlerinden nakit çıkışına sahipken, finansman faaliyetlerinden nakit girişi elde etmektedir (-, -, +). Bu modele göre işletmenin esas faaliyetlerinden ve yatırımlarından negatif nakit akışına sahip olması ya borçlanma ya da özsermayede yapılan artışlarla karşılanmaktadır. Modelde işletmenin büyüdüğü ve negatif nakit akışlarının geçici bir durumu işaret ettiği kabul edilmektedir. İşletmenin hızla yükselen satışlarını sürdürebilmek için, işletme sermayesi unsurları olan alacaklar ve stoklar gibi kalemlere yöneldiği veya kısa vadeli borçlarını ödediği söylenebilir.

Model 7 (Likiditasyon Modeli): Bu modelde işletme faaliyetleri ve finansman faaliyetlerinden kaynaklanan nakit akışları negatif buna karşın yatırım faaliyetleriyle ilgili nakit akışları pozitiftir (-, +, -). Bu modele göre işletmenin borçlarını ödemek için sabit varlık yatırımlarını elden çıkardığı ve bu durumun olağan olmadığı ve işletmenin birçok varlığı elden çıkaracağı (likiditasyon) belki de iflas edeceği sonucu çıkarılmaktadır.

Model 8 (Nadir Durum): Bu modelde; işletme, yatırım ve finansman faaliyetlerinden elde edilen nakit akışları negatiftir (-, -, -). Bu modele göre bütün faaliyetlerden negatif nakit akışı elde edilmesinin nedeni daha önce birikmiş ve yapılması gereken nakit çıkışlarının yapılması olarak görülmektedir. Bu modelde ifade edilen profilin nadir olarak rastlanan bir profil olduğu kabul edilmektedir.

\section{Literatür Taraması}

Konuyla ilgili literatür incelendiğinde turizm sektörü dışında farklı sektörlerdeki işletmelerin finansal performanslarını veya iflas risklerini nakit akış tablosu, nakit akış rasyoları ve nakit akış profillerini kullanarak ölçmeyi hedeflemiş çalışmaların varlığı 
dikkat çekmektedir. Buna karşın konaklama işletmelerinin nakit akış profillerini belirlemeye yönelik bir çalışmaya tarafımızca rastlanmamıştır.

Gup ve diğ. (1993), 1745 işletmenin finansal performansını ve nakit akışı profillerini nakit akışlarının sağlandığı faaliyetler yöntemine göre incelemişlerdir. Çalışma sonunda analize dahil işletmelerin \%45'nin Model 2'ye dahil olduğunu, diğer bir ifadeyle işletme faaliyetlerinden pozitif, yatırım ve finansman faaliyetlerinden negatif nakit akışlarına sahip olduklarını ve başarılı işletme profili gösterdiklerini belirlemişlerdir. Çalışmada ayrıca ikinci sırada, analize dahil işletmelerin yaklaşık \%35'inin Model 4 içerisinde oldukları belirlenmiştir. Üçüncü sırada ise Model 6 ve Model 3profiline sahip işletmeler yer almaktadır.

Bruwer ve Hamman (2005), Gup ve diğerlerinin (1993) yaptıkları modellemeyi Güney Afrika'daki şirketler üzerinde işletme yaşam seyri yaklaşımıyla birleştirerek nakit akışları ile ilişkilendirmişlerdir. Çalışma sonucunda incelenen şirketlerin nakit akış profillerinin Model 2'ye daha fazla dahil olduğunu ve bu bağlamda işletme yaşam seyri sürecinde olgunluk aşamasında bulundukları belirlenmiştir.

Karğın ve Aktaş (2011), nakit akış tablosunun analiz edilmesinin bir işletmenin finansal performansı hakkında daha güvenilir sonuçlar vereceğini vurgulayarak bir çalışma gerçekleştirmişlerdir. Bu amaçla halka açık bir inşaat şirketinin 2006-2010 yıllarına ait nakit akış tabloları, yatay analiz, trend analizi, oran analizi ve nakit akışlarının sağlandığı faaliyetler modeli kullanılarak analiz edilmiştir. Çalışma sonucunda nakit akışlarının sağlandığı faaliyetler modelinin diğer analiz teknikleri ile beraber işletme hakkında daha ayrıntılı ve daha isabetli analiz sonuçların alınmasını sağladığı ortaya konulmuştur. Ayrıca analiz edilen şirketin analiz süreci boyunca sadece 2008 yılı dışında Model 2'nin işaret ettiği nakit akış profiline sahip olduğu belirlenmiştir.

Kordestani ve diğ. (2011), nakit akış tablosunda bulunan işletme, yatırım ve finansman faaliyetlerinden elde edilen nakit akışlarının profilleri kullanılarak işletmelerin finansal sıkıntı ve iflas risklerinin tahmin edilmesinde bir model geliştirmek amacıyla bir çalışma gerçekleştirmişlerdir. Bu amaçla Tahran Menkul Kıymetler Borsası'nda 19952008 yılları arasında işlem gören ve finansal sıkıntı içerisinde olan 70 şirketin nakit akış tablolarını ve nakit akışlarını incelemişlerdir. Çalışma sonunda nakit akış profillerinin finansal sıkıntıyı önceden tahmin etmede etkin olduğu saptanmıştır.

Aktaş ve diğ. (2012), Türkiye'de borsada işlem gören 176 işletmenin 2007-2010 yıllarını kapsayan nakit akış tablolarını, nakit akışlarının sağlandığı faaliyetler yöntemine göre analiz etmişlerdir. Analiz; yıl, sektör ve işletmelerin aktif büyüklüğüne göre gerçekleştirilmiştir. Araştırmanın sonuçlarına göre, incelenen işletmelerin nakit akışlarının, yıl, sektör ve aktif büyüklükleri temelinde, Model 2 (başarılı işletme), Model 4 (büyüyen işletme) ve Model 6 (hızlı büyüyen-genç işletme) profillerinde yoğunlaştığı saptanmıştır.

Orhan ve Başar (2015), Borsa İstanbul 100 Endeksi'nde yer alan şirketlerin nakit akış profillerini belirlemek ve nakit akış profilleri ile bazı seçilmiş finansal oranlar arasındaki ilişkiyi belirlemek amacıyla bir çalışma gerçekleştirmişlerdir. Bu amaçla 3 spor şirketi, 33 finansal şirket ve verilerine ulaşılamayan 9 şirket dışında yer alan 55 şirketin 2008-2013 yılları arasındaki finansal tabloları üzerinde analiz gerçekleştirilmiştir. Analiz neticesinde analize dahil şirketlerin en fazla Model 2'ye uygun nakit akış profiline sahip olduğu belirlenmiştir. Çalışmada ayrıca nakit akış profili Model 2 içerisinde bulunan şirketlerin aktif büyüklüğü ortalamasının diğer modellerden 
yüksek olduğu, borç/aktif toplamı oranının ise daha düşük olduğu belirlenmiştir. Yine Model 4 içerisinde yer alan işletmelerin en yüksek aktif büyüme oranına sahip oldukları saptanmıştır. Model 6 içerisinde yer alan işletmelerin ise en yüksek borç/aktif toplamı oranına sahip oldukları saptanmıştır.

Shamsudin ve Kamaluddin (2015), finansal sıkıntı içinde olan ve finansal açıdan güçlü olan işletmelerde iflas riskini nakit akış profillerine göre tahmin etmek ve aradaki nakit akışı profilleri arasındaki farklılıkları belirlemek amacıyla bir çalışma gerçekleştirmişlerdir. Bu kapsamda Malezya'da 2006-2013 yılları arasında borsada işlem gören 124 halka açık işletmenin nakit akış profilleri analiz edilmiştir. Analiz sonucunda, finansal sıkıntı içerisinde bulunan işletmelerin günlük faaliyetlerinden nakit girişi elde ettikleri ve bu nakit girişlerini gelecekteki yatırımlarının veya uzun vadeli borçlarının finansmanında kullandıkları belirlenmiştir. Yine finansal sıkıntı içerisinde bulunan şirketlerin kısa vadeli borçlarını, esas faaliyetlerinden elde ettikleri nakit girişleriyle karşılamada güçlükle karşılaştıkları ve bu nedenle dışsal kaynaklara yöneldikleri saptanmıştır. Ayrıca işletme, yatırım ve finansman faaliyetlerinden negatif nakit akışına sahip işletmelerin iflas eğiliminin güçlü olduğu belirlenmiştir. Son olarak nakit akışı profillerinin finansal açıdan sağlıklı şirketler ile finansal sıkıntı içerisindeki şirketler arasında farklıık gösterdiği saptanmıştır.

\section{Veri ve Yöntem}

$\mathrm{Bu}$ çalışmada halka açık konaklama işletmelerinin nakit akış profillerinin uluslararası olarak karşılaştırmalı analiz edilmesi amaçlanmaktadır. Bu amaçla Amerika, Avrupa ve Asya-Pasifik ülkelerindeki borsalarda işlem gören konaklama işletmelerinin 2013-20142015 yıllarına ait nakit akış tabloları analiz edilmiştir. Bu amaca yönelik olarak Gup ve diğ. (1993) tarafından geliştirilen ve yukarıda açıklanan nakit akışlarının sağlandığı faaliyetler yöntemi kullanılmıştır. Konaklama işletmelerinin verileri Financial Times piyasa verileri kısmından elde edilmiştir (http://markets.ft.com/data/equities/results).

Analize, Amerika kıtasından beş ülke borsasında işlem gören toplam yirmi beş konaklama işletmesi dahil edilmiştir. Aşağıdaki tabloda Amerika kıtasından analize dahil edilen ülke ve bu ülkelerdeki borsalarda işlem gören konaklama işletmelerinin isimleri verilmektedir.

Tablo 3: Amerika Kıtasındaki Halka Açık Konaklama İşletmeleri

\begin{tabular}{|l|l|}
\hline \multicolumn{1}{|c|}{ Ülke } & \multicolumn{1}{c|}{ Konaklama Isşetmeleri } \\
\hline Amerika Birleşik & Belmond Ltd., China Lodging Group, Choice Hotels International, Diamond \\
Devletleri (ABD) & $\begin{array}{l}\text { Resorts Holdings, Extended Stay America, Hyatt Hotels Corporation, Hilton } \\
\text { Worldwide Holdings Inc., Host Hotels \& Resorts Inc., Intercontinental Hotels } \\
\text { Group, La Quinta Holdings Inc., Marriott International Inc., Morgans Hotel } \\
\\
\text { Group Co., Red Lion Hotels Corporation, Starwood Hotels \& Resorts } \\
\text { Worldwide, Wyndham Worldwide Corporation, Temple Hotels Inc. }\end{array}$ \\
\hline Arjantin & Compania Hotelera Argentina SA \\
\hline Brezilya & Hoteis Othon SA, Sauipe SA \\
\hline Kanada & $\begin{array}{l}\text { Allied Hotel Properties Inc, Mountain China Resorts Holding Ltd., Whistler } \\
\text { Blackcomb Holdings Inc. }\end{array}$ \\
\hline Meksika & $\begin{array}{l}\text { Grupo Hotelero Santa Fe SAB de CV, Hoteles City Express SAB de CV, } \\
\text { Grupo Posadas SAB de CV }\end{array}$ \\
\hline
\end{tabular}

Yukarıdaki tablo incelendiğinde ABD'den on altı, Arjantin'den bir, Brezilya'dan iki, Kanada ve Meksika'dan da üç konaklama işletmesinin analiz kapsamında olduğu görülmektedir. 
Çalışmada Avrupa kıtasındaki on üç ülke borsasında işlem gören elli bir konaklama işletmesi analize dahil edilmiştir. Aşağıdaki tabloda Avrupa kıtasından analize dahil edilen ülkelerin ve bu ülkelerdeki borsalarda işlem gören konaklama işletmelerinin isimleri verilmektedir. Tablo 4 incelendiğinde İngiltere'den on bir, Türkiye'den dokuz, Fransa'dan yedi, Bulgaristan'dan beş, Yunanistan'dan dört, Almanya ve Romanya'dan üç, Polonya, İspanya ve Slovenya'dan iki, İrlanda, Portekiz ve İsveç'ten bir konaklama işletmesinin analiz kapsamında olduğu görülmektedir.

Tablo 4: Avrupa Kıtasındaki Halka Açık Konaklama İşletmeleri

\begin{tabular}{|l|l|}
\hline \multicolumn{1}{|c|}{ Ülke } & \multicolumn{1}{|c|}{ Konaklama İşletmeleri } \\
\hline Türkiye & $\begin{array}{l}\text { Altınyunus Çeşme Turistik Tesisler AŞ., Kuştur Kuşadası Turizm Endüstri AŞ., } \\
\text { Marmaris Altınyunus Turistik Tesisler AŞ., Martı Otel İşletmeleri AŞ., Metemtur } \\
\text { Otelcilik ve Turizm Işletmeleri AŞ., Net Turizm ve Ticaret ve Sanayi AŞ., } \\
\text { Petrokent Turizm AŞ., Tek-Art İnşaat Tic.Turizm Sanayi ve Yatırımlar AŞ., } \\
\text { Ütopya Turizm İnşaat İşletmecilik Ticaret AŞ. }\end{array}$ \\
\hline $\begin{array}{l}\text { Yunanist } \\
\text { an }\end{array}$ & $\begin{array}{l}\text { Ionıan Hotel Ent.,Geke SA., Astır Palace Voulıagmeni SA, Lampsa Hellenic } \\
\text { Hotels SA }\end{array}$ \\
\hline Fransa & $\begin{array}{l}\text { Accor SA, Bernard Loiseau SA, Hotelim SA, Les Hotels Baverez SA, Les Hotels } \\
\text { De Paris SA, Pierre Et Vacances SA, Societe Immobiliere Et D'exploitation Hotel } \\
\text { Majestic SA }\end{array}$ \\
\hline $\begin{array}{l}\text { Bulgarist } \\
\text { an }\end{array}$ & $\begin{array}{l}\text { Albena AD, Sofia Hotel Balkan AD, St Constantine and Helena Holding AD, } \\
\text { Velina AD, Zlatni Pyasatsi AD }\end{array}$ \\
\hline Almanya & Design Hotels AG, IFA Hotel \& Touristik AG, Regenbogen AG \\
\hline Polonya & Interferie SA, Orbis SA \\
\hline Slovenya & Terme Cadezdd, Union Hoteli dd \\
\hline İlanda & Dalata Hotel Group PLC \\
\hline Portekiz & Imobiliaria Construtora Grao Para SA \\
\hline İsveç & Rezidor Hotel Group AB \\
\hline İngiltere & $\begin{array}{l}\text { Action Hotels PLC, Dalata Hotel Group PLC, Elegant Hotels Group PLC, } \\
\text { Intercontinental Hotels Group, J D Wetherspoon PLC, Millennium \& Copthorne } \\
\text { Hotels PLC, Mineon Group PLC, PPHE Hotel Group Ltd., Safestay PLC, } \\
\text { Whitbread PLC }\end{array}$ \\
\hline Romanya & $\begin{array}{l}\text { Casa de Club de Munte SA, Compania Hoteliera Inter Continental Romania SA, } \\
\text { Turism Hoteluri Restaurante Marea Neagra SA }\end{array}$ \\
\hline İspanya & Meliá Hotels International, NH Hoteles \\
\hline
\end{tabular}

Çalışmada Asya-Pasifik kıtasından ise on altı ülke borsasında işlem gören yüz otuz bir konaklama işletmesi analize dahil edilmiştir. Aşağıdaki tabloda Asya-Pasifik kıtasından analize dahil edilen ülkelerin ve bu ülkelerdeki borsalarda işlem gören konaklama işletmelerinin isimleri verilmektedir. Tablo 5 incelendiğinde Sri Lanka'dan otuz iki, Hong Kong'dan on beş, Hindistan'dan on üç, Tayland'dan on, Japonya'dan ve Singapur'dan dokuz, Endonezya'dan ve Tayvan'dan sekiz, Umman'dan yedi, Filipinler'den beş, Avusturalya, Çin İsrail ve Malezya'dan üç, Pakistan'dan iki ve Yeni Zelanda'dan bir halka açık konaklama işletmesinin analiz kapsamında olduğu görülmektedir.

Tablo 5: Asya-Pasifik Kıtasındaki Halka Açık Konaklama İşletmeleri

\begin{tabular}{|l|l|}
\hline \multicolumn{1}{|c|}{ Ülke } & \multicolumn{1}{|c|}{ Konaklama Işletmeleri } \\
\hline Avusturalya & Donaco International Ltd., Mantra Group Ltd., Newhaven Hotels Ltd. \\
\hline Çin & $\begin{array}{l}\text { BTG Hotels Group Co Ltd., Jinling Hotel Corp Ltd., Shanghai Jin Jiang } \\
\text { International Hotels Development Co., Ltd }\end{array}$ \\
\hline
\end{tabular}


Tablo 5'in Devamı

\begin{tabular}{|c|c|}
\hline Hong Kong & $\begin{array}{l}\text { Asia Standart Hotel, Associated International Hotels Ltd., Emperor } \\
\text { Entertainment Hotel Ltd., Far East Hotels and Entertainment Ltd., Hong Kong } \\
\text { and Shanghai Hotels Ltd., Magnificent Hotel Investment Ltd., Miramar Hotel and } \\
\text { Investment Co Ltd., MGM China Holdings Ltd., Regal Hotels International } \\
\text { Holdings Ltd., Rosedale Hotel Holdings Ltd., Shangai Jin Jiang International } \\
\text { Hotels Group Co Ltd., Shangri-La Asia Ltd., Shun Cheong Holdings Ltd., Shun } \\
\text { Ho Holdings Ltd., Sino Hotels Holdings Ltd. }\end{array}$ \\
\hline Hindistan & $\begin{array}{l}\text { Advani Hotels and Resorts India Ltd., Asian Hotels North Ltd., Blue Coast } \\
\text { Hotels Ltd., Byke Hospitality Ltd., ElH Associated Hotels Ltd., ElH Ltd., Hotel } \\
\text { Leelaventure Ltd., Indian Hotels Company Ltd., Kamat Hotels (India) Ltd., } \\
\text { Oriental Hotels Ltd., Royal Orchid Hotels Ltd., TAJ GVK Hotels and Resorts, } \\
\text { Viceroy Hotels Ltd. }\end{array}$ \\
\hline Endonezya & $\begin{array}{l}\text { Grahamas Citrawisata Tbk PT, Hotel Mandarine Regency Tbk PT, Hotel Sahid } \\
\text { Jaya International Tbk PT, Jakarta Setiabudi Internasional Tbk PT, } \\
\text { Pembangunan Graha Lestari Indah Tbk PT, Plaza Indonesia Realty Tbk PT, } \\
\text { Pudjiadi and Sons Tbk PT, Red Planet Indonesia Tbk PT }\end{array}$ \\
\hline İsrail & Dan Hotels Ltd., HofGai Ltd., Isrotel Ltd. \\
\hline Japonya & $\begin{array}{l}\text { Agora Hospitality Group Co Ltd., Fujita Kanko Inc, Hotel Newgrand Co Ltd., } \\
\text { Imperial Hotel Ltd., Kamogawa Grand Hotel Ltd., Kyoto Hotel Ltd., Nippon View } \\
\text { Hotel Co Ltd., Oriental Land Co Ltd., Royal Hotel Ltd }\end{array}$ \\
\hline Malezya & Grand Central Enterprises Bhd., Landmarks Bhd., Reliance Pacific Bhd \\
\hline Yeni Zelanda & Millenium \& Copthorne Hotels New Zealand Ltd. \\
\hline Umman & $\begin{array}{l}\text { Al Batinah Hotels Co SAOG, Al Buraimi Hotel Co SAOG, Gulf Hotels Oman Co } \\
\text { Ltd SAOG, Hotels Management International Co SAOG, Oman Hotels and } \\
\text { Tourism Co SAOG, Sahara Hospitality Co SAOG, Ubar Hotels and Resorts Co } \\
\text { SAOG }\end{array}$ \\
\hline Pakistan & Pakistan Hotels Developers Ltd., Pakistan Services Ltd. \\
\hline Filipinler & $\begin{array}{l}\text { Acesite (Phils.) Hotel Corp., Bloombery Resorts Corp., Discovery World Corp., } \\
\text { Travellers International Hotel Group Inc, Waterfront Philippines Inc }\end{array}$ \\
\hline Singapur & $\begin{array}{l}\text { AF Global Ltd, Amara Holdings Ltd, Banyan Tree Holdings Ltd., GL Ltd., Global } \\
\text { Premium Hotels Ltd., Hotel Grand Central Ltd., Hotel Properties Ltd., Mandarin } \\
\text { Oriental International Ltd., OUE Ltd. }\end{array}$ \\
\hline Sri Lanka & $\begin{array}{l}\text { Aitken Spence Hotel Holdings PLC, Amaya Leisure PLC, Beruwala Resorts } \\
\text { PLC, Ceylon Hotels Corporation PLC, Citrus Leisure PLC, Dolphin Hotels PLC, } \\
\text { Eden Hotel Lanka PLC, Fortress Resorts PLC, Galadari Hotels PLC, } \\
\text { Hikkaduwa Beach Resort PLC, Hotel Developers PLC, Hotel Sigiriya PLC, } \\
\text { Hunas Falls Hotels PLC, John Keels Hotels PLC, Kalpitiya Beach Resort PLC, } \\
\text { Kandy Hotels Company PLC, Kingsbury PLC, Lighthouse Hotel PLC, Mahaweli } \\
\text { Reach Hotel PLC, Marawila Resorts PLC, Nuwara Eliya Hotels Co PLC, Palm } \\
\text { Garden Hotels PLC, Pegasus Hotels of Ceylon PLC, Ramboda Falls PLC, } \\
\text { Renuka City Hotel PLC, Royal Palms Beach Hotels PLC, Serendib Hotels PLC, } \\
\text { Sigiriya Village Hotels PLC, Tal Lanka Hotels PLC, Tangerine Beach Hotels } \\
\text { PLC, Trans Asia Hotels PLC, Waskaduwa Beach Resort PLC }\end{array}$ \\
\hline Tayvan & $\begin{array}{l}\text { Ambassador Hotel Ltd., Chateau International Development Co Ltd., Far Glory } \\
\text { Hotel Co Ltd., First Hotel Co Ltd., Formosa International Hotels Corp., Hotel } \\
\text { Holiday Garden, Leofoo Development Co Ltd., My Humble House Hospitality } \\
\text { Management Consulting Co Ltd. }\end{array}$ \\
\hline Tayland & $\begin{array}{l}\text { Asia Hotel PLC, Central Plaza Hotel PCL, Dusit Thani PCL, Erawan Group } \\
\text { PCL, Grande Asset Hotels and Property PCL, Laguna Resorts and Hotels PCL, } \\
\text { Mandarin Hotel PCL, OTHL PCL, Royal Orchid Hotel Thailand PCL, Shangri La } \\
\text { Hotel PCL }\end{array}$ \\
\hline
\end{tabular}

\section{Bulgular}

Çalışmanın amaçları doğrultusunda Amerika, Avrupa ve Asya-Pasifik kıtalarında yer alan toplam 207 halka açık konaklama işletmesinin 2013-2014-2015 yıllarına ait nakit 
akış tabloları incelenmiş, bu işletmelerin işletme, yatırım ve finansman faaliyetlerinden elde ettikleri nakit akışlarının pozitif veya negatif olup olmadıkları değerlendirilmiştir. Bu bağlamda 207 halka açık konaklama işletmesinin yıllık verileri bağlamında 621, analiz süresince de 1863 adet gözlem gerçekleştirilmiştir. Gözlem sonuçları Gup ve diğ. (1993) tarafından geliştirilen nakit akışlarının sağlandığı faaliyetler yöntemi kullanılarak yıl, kıta ve Türkiye temelinde analiz edilmiş ve bu işletmelerin nakit akış profilleri belirlenmeye çalışılmıştır.

Çalışmada Amerika kıtasından ele alınan yirmi beş halka açık konaklama işletmesinin 2013-2014-2015 yıllarına ait nakit akış tabloları incelendiğinde Tablo 6' da özetlenen bulgulara ulaşılmıştır.

Tablo 6: Amerika Kıtasındaki Halka Açık Konaklama İşletmelerinin Nakit Akış Profilleri

\begin{tabular}{|l|c|c|c|c|c|c|c|}
\hline \multirow{2}{*}{ Modeller } & \multicolumn{2}{|c|}{$\mathbf{2 0 1 3}$} & \multicolumn{2}{c|}{ 2014 } & \multicolumn{2}{c|}{ 2015 } & $\begin{array}{c}\text { 3 Yıllık } \\
\text { Yüzdelik } \\
\text { Ortalama }\end{array}$ \\
\cline { 2 - 8 } & $\%$ & Sayı & $\%$ & Sayı & $\%$ & Sayı & \\
\hline Model 1 (+,+,+) & 0,04 & 1 & 0,00 & 0 & 0,00 & 0 & 0,01 \\
\hline Model 2 (+,-,-) & 0,40 & 10 & 0,40 & 10 & 0,44 & 11 & 0,41 \\
\hline Model 3 (+,+,-) & 0,12 & 3 & 0,12 & 3 & 0,28 & 7 & 0,17 \\
\hline Model 4 (+,-,+) & 0,16 & 4 & 0,36 & 9 & 0,24 & 6 & 0,25 \\
\hline Model 5 (-,+,+) & 0,00 & 0 & 0,00 & 0 & 0,00 & 0 & 0,00 \\
\hline Model 6 (-,-,+) & 0,16 & 4 & 0,08 & 2 & 0,04 & 1 & 0,09 \\
\hline Model 7 (-,+,-) & 0,08 & 2 & 0,00 & 0 & 0,00 & 0 & 0,03 \\
\hline Model 8 (-,-,-) & 0,04 & 1 & 0,04 & 1 & 0,00 & 0 & 0,03 \\
\hline Toplam & 1,00 & 25 & 1,00 & 25 & 1,00 & 25 & 1,00 \\
\hline
\end{tabular}

Analiz döneminde Amerika kıtasındaki halka açık konaklama işletmelerinin nakit akış profilleri dahil oldukları modeller dikkate alınarak değerlendirildiğinde "Model $2(+,-$ ,-) başarılı işletme" en çok gözlenen nakit akış profili olurken, "Model4 $(+,-,+)$ büyüyen işletme" ikinci en çok gözlenen, "Model $3(+,+,-)$ gerileyen veya yeniden yapılanan" ise üçüncü en çok gözlenen nakit akış profili olduğu belirlenmiştir. Yıllar itibariyle yapılan incelemede, 2013 yılında analiz kapsamındaki konaklama işletmelerinde en çok görülen nakit akış profili \%40 ile Model 2, \%16 ile Model 4 ve Model 6 (genç işletme), $\% 12$ ile Model 3 profilidir. 2014 yılında analiz kapsamındaki konaklama işletmelerinde en çok görülen nakit akış profili yine \%40 ile Model 2, \%36 ile Model 4, \%12 ile Model 3'tür. 2015 yılında ise yine analiz kapsamındaki konaklama işletmelerinde en çok görülen nakit akış profili yine \%44 ile Model 2, \%28 ile Model 3, \%24 ile Model 4'tür. Dolayısıyla analiz dönemindeki bütün yıllar için Amerika kıtasındaki halka açık konaklama işletmelerinde Model 2 profilinin yaygın olarak görüldüğü söylenebilir. Bu profildeki işletmeler başarılı işletmeler olarak kabul edilmektedir. İkinci olarak Model 4'e ve üçüncü olarak da Model 3'e giren nakit akış profilinin yaygın olduğu saptanmıştır. 2013-2015 yıllarında Model 3 profilindeki işletmelerin oranı sırasıyla \%12, \%12 ve \%28'dir. Dolayısıyla 2015 yılında gerileyen konaklama işletmesi sayısında artış gözlemlenmektedir. 
Çalışmada Avrupa kıtasından analize dahil edilen elli bir halka açık konaklama işletmesinin 2013-2014-2015 yıllarına ait nakit akış tabloları incelendiğinde Tablo 7'de özetlenen bulgulara ulaşılmıştır.

Tablo 7: Avrupa Kıtasındaki Halka Açık Konaklama İşletmelerinin Nakit Akış Profilleri

\begin{tabular}{|c|c|c|c|c|c|c|c|}
\hline \multirow{2}{*}{ Modeller } & \multicolumn{2}{|c|}{2013} & \multicolumn{2}{|c|}{2014} & \multicolumn{2}{|c|}{2015} & \multirow{2}{*}{$\begin{array}{c}3 \text { Yıllık } \\
\text { Yüzdelik } \\
\text { Ortalama }\end{array}$} \\
\hline & $\%$ & Sayı & $\%$ & Sayı & $\%$ & Sayı & \\
\hline Model $1(+,+,+)$ & 0,00 & 0 & 0,00 & 0 & 0,00 & 0 & 0,00 \\
\hline Model $2(+,-,-)$ & 0,47 & 24 & 0,43 & 22 & 0,53 & 27 & 0,48 \\
\hline Model $3(+,+,-)$ & 0,12 & 6 & 0,18 & 9 & 0,10 & 5 & 0,13 \\
\hline Model $4(+,-,+)$ & 0,25 & 13 & 0,33 & 17 & 0,24 & 12 & 0,27 \\
\hline Model $5(-,+,+)$ & 0,06 & 3 & 0,02 & 1 & 0,02 & 1 & $\overline{0,03}$ \\
\hline Model $6(-,-,+)$ & 0,06 & 3 & 0,04 & 2 & 0,10 & 5 & 0,07 \\
\hline Model $7(-,+,-)$ & 0,02 & 1 & 0,00 & 0 & 0,02 & 1 & 0,01 \\
\hline Model $8(-,-,-)$ & 0,02 & $\overline{1}$ & 0,00 & 0 & 0,00 & 0 & 0,01 \\
\hline Toplam & 1,00 & 51 & 1,00 & 51 & 1,00 & 51 & 1,00 \\
\hline
\end{tabular}

Analiz döneminde Avrupa kıtasındaki halka açık konaklama işletmelerinin nakit akış profilleri dahil oldukları modeller dikkate alınarak değerlendirildiğinde "Model $2(+,-$ ,-) başarılı işletme" en çok gözlenen nakit akış profili olurken, "Model $4(+,-,+)$ büyüyen işletme" ikinci en çok gözlenen, "Model $3(+,+,-)$ gerileyen veya yeniden yapılanan" ise üçüncü en çok gözlenen nakit akış profili olduğu belirlenmiştir. Yıllar itibariyle yapılan incelemede, 2013 yılında analiz kapsamındaki konaklama işletmelerinde en çok görülen nakit akış profili \%47 ile Model 2, \%25 ile Model 4 ve \%12 ile Model 3 profilidir. 2014 yılında analiz kapsamındaki konaklama işletmelerinde en çok görülen nakit akış profili yine \%43 ile Model 2, \%33 ile Model 4 ve \%18 ile Model 3'tür. 2015 yılında ise yine analiz kapsamındaki konaklama işletmelerinde en çok görülen nakit akış profili yine \%53 ile Model 2, \%24 ile Model 4, \%10 ile Model 3 ve Model 6'dır. 2015 yılında, hızlı büyüyen genç işletme olarak tanımlanan Model 6'ya giren konaklama işletmesi sayısında artış gözlemlenmektedir.

Çalışmada Avrupa kıtasından analize dahil edilen Türkiye'deki dokuz halka açık konaklama işletmesinin 2013-2014-2015 yıllarına ait nakit akış tabloları incelendiğinde Tablo 8'de özetlenen bulgulara ulaşılmıştır. Tablo 8 incelendiğinde analize dahil edilen Türkiye'deki halka açık dokuz adet konaklama işletmesinde "Model $2(+,-,-)$ başarılı işletme" en çok gözlenen nakit akış profili olurken, "Model $4(+,-,+)$ büyüyen işletme" ikinci en çok gözlenen, "Model $3(+,+,-)$ gerileyen veya yeniden yapılanan" ise üçüncü en çok gözlenen nakit akış profili olduğu görülmektedir. 
Tablo 8: Türkiye'deki Halka Açık Konaklama İşletmelerinin Nakit Akış Profilleri

\begin{tabular}{|l|c|c|c|c|c|c|c|}
\hline \multirow{2}{*}{ Modeller } & \multicolumn{2}{|c|}{2013} & \multicolumn{2}{c|}{$\mathbf{2 0 1 4}$} & \multicolumn{2}{c|}{ 2015 } & \multirow{3}{*}{$\begin{array}{c}\text { 3 Yıllık } \\
\text { Yüzdelik } \\
\text { Ortalama }\end{array}$} \\
\cline { 2 - 8 } & $\%$ & Sayı & $\%$ & Sayı & $\%$ & Sayı & \\
\hline Model 1 (+,+,+) & 0,00 & 0 & 0,00 & 0 & 0,00 & 0 & 0,00 \\
\hline Model 2 (+,-,-) & 0,44 & 4 & 0,44 & 4 & 0,44 & 4 & 0,44 \\
\hline Model 3 (+,+,-) & 0,00 & 0 & 0,33 & 3 & 0,22 & 2 & 0,19 \\
\hline Model 4 (+,-,+) & 0,33 & 3 & 0,22 & 2 & 0,11 & 1 & 0,22 \\
\hline Model 5 (-,+,+) & 0,11 & 1 & 0,00 & 0 & 0,00 & 0 & 0,04 \\
\hline Model 6 (-,-,+) & 0,00 & 0 & 0,00 & 0 & 0,22 & 2 & 0,07 \\
\hline Model 7 (-,+,-) & 0,11 & 1 & 0,00 & 0 & 0,00 & 0 & 0,04 \\
\hline Model 8 (-,-,-) & 0,00 & 0 & 0,00 & 0 & 0,00 & 0 & 0,00 \\
\hline Toplam & 1,00 & 9 & 1,00 & 9 & 1,00 & 9 & 1,00 \\
\hline
\end{tabular}

Analiz dönemi olan 2013-2014-2015 yıllarının ortalaması alındığında analize dahil dokuz konaklama işletmesinin \%44'ü Model 2'de, \%22'si Model 4'te, \%19'u ise Model 3'te yer aldığı belirlenmiştir. 2013 yılında Model3 (gerileyen veya yeniden yapılanan) profilinde işletme olmamasına rağmen 2014 yılında üç, 2015 yılında ise iki konaklama işletmesinin bu profilde yer aldığı belirlenmiştir. Model 4'teki işletme sayısının ise analiz döneminde yıllar itibariyle azaldığı saptanmıştır. 2013 yılında Model 5(küçülen işletme) profiline ve Model 7 (likiditasyona giden işletme) profiline birer işletme girerken 2014 ve 2015 yıllarında Model 5 ve Model 7 profilleri içerisinde herhangi bir işletme olmamıştır. Yine 2015 yılında Model 6 (hızlı büyüyen- genç işletme) profiline iki işletmenin girmesi de dikkat çekicidir.

Tablo 9: Asya-Pasifik Kıtasındaki Halka Açık Konaklama İşletmelerinin Nakit Akış Profilleri

\begin{tabular}{|l|c|c|c|c|c|c|c|}
\hline \multirow{2}{*}{ Modeller } & \multicolumn{2}{|c|}{2013} & \multicolumn{2}{c|}{ 2014 } & \multicolumn{2}{c|}{ 2015 } & \multirow{3}{*}{$\begin{array}{c}\text { Y Ylllk } \\
\text { Yüzdelik } \\
\text { Ortalama }\end{array}$} \\
\cline { 2 - 8 } & $\%$ & Sayı & $\%$ & Sayı & $\%$ & Sayı & \\
\hline Model 1 (+,+,+) & 0,00 & 0 & 0,02 & 2 & 0,01 & 1 & 0,01 \\
\hline Model 2 (+,-,-) & 0,51 & 67 & 0,52 & 68 & 0,50 & 66 & 0,51 \\
\hline Model 3 (+,+,-) & 0,11 & 14 & 0,13 & 17 & 0,13 & 17 & 0,12 \\
\hline Model 4 (+,-,+) & 0,27 & 35 & 0,24 & 32 & 0,27 & 36 & 0,26 \\
\hline Model 5 (-,+,+) & 0,02 & 2 & 0,01 & 1 & 0,01 & 1 & 0,01 \\
\hline Model 6 (-,-,+) & 0,08 & 10 & 0,05 & 7 & 0,05 & 6 & 0,06 \\
\hline Model 7 (-,+,-) & 0,02 & 3 & 0,02 & 3 & 0,01 & 1 & 0,02 \\
\hline Model 8 (-,-,-) & 0,00 & 0 & 0,01 & 1 & 0,02 & 3 & 0,01 \\
\hline Toplam & 1,00 & 131 & 1,00 & 131 & 1,00 & 131 & 1,00 \\
\hline
\end{tabular}


Çalışmada Asya-Pasifik kıtasından analize dahil edilen yüz otuz bir halka açık konaklama işletmesinin 2013-2014-2015 yıllarına ait nakit akış tabloları incelendiğinde Tablo 9'da özetlenen bulgulara ulaşılmıştır. Analiz döneminde Asya-Pasifik ülkelerindeki halka açık konaklama işletmelerinin nakit akış profilleri dahil oldukları modeller dikkate alınarak değerlendirildiğinde "Model $2(+,-,-)$ başarılı işletme" en çok gözlenen nakit akış profili olurken, "Model $4(+,-,+)$ büyüyen işletme" ikinci en çok gözlenen, "Model $3(+,+,-)$ gerileyen veya yeniden yapılanan" ise üçüncü en çok gözlenen nakit akış profili olduğu belirlenmiştir.

Yıllar itibariyle yapılan incelemede, Asya-Pasifik kıtasında, 2013 yılında analiz kapsamındaki konaklama işletmelerinde en çok görülen nakit akış profili \%51 ile Model 2, \%27 ile Model 4 ve \%11 ile Model 3 profilidir. 2014 yılında analiz kapsamındaki konaklama işletmelerinde en çok görülen nakit akış profili yine \%52 ile Model 2, \%24 ile Model 4 ve \%13 ile Model 3'tür. 2015 yılında ise yine analiz kapsamındaki konaklama işletmelerinde en çok görülen nakit akış profili yine \%50 ile Model 2, \%27 ile Model 4, \%17 ile Model 3'tür. Ayrıca üç yıllık analiz sürecinde, hızlı büyüyen genç işletme olarak tanımlanan Model 6'ya giren konaklama işletmesi sayısının toplam işletme sayısındaki payının ortalama \%6 olduğu gözlemlenmektedir.

\section{Sonuç ve Öneriler}

Son yıllarda yaşanan finansal ve politik krizler, döviz kurlarındaki ve faiz oranlarındaki dalgalanmalar, ülke risklerindeki artışlar ve yoğun rekabet ortamı işletmelerin faaliyetlerini sürdürebilirlik temelinde devam ettirmeleri ve finansal güçlerini sağlıklı bir şekilde koruyabilmelerini zorlaştırabilmektedir. Bu süreçte gelir ve gider-maliyet planlamasının yapılması güçleşmekte ve sorunlar ortaya çıkabilmektedir. Genel olarak gelir ile maliyet arasındaki olumlu fark olarak tanımlanan kar, işletmeler açısından önemli bir performans göstergesi olarak tanımlansa da tek başına operasyonel ve finansal başarının göstergesi olmayabilir. İşletmeler faaliyetleri sonucunda yüksek bir kara sahip olsalar da faaliyetlerini sürdürebilmek, vadesi gelen yükümlülüklerini karşılayabilmek, reel yatırım gerçekleştirmek, ortaya çıkan iş fırsatlarını değerlendirmek ve ortaya çıkabilecek ödemeleri gerçekleştirmek için intiyaç duydukları nakdi yaratamazlarsa nakde intiyaç duyarlar. Bütün bu unsurlar için işletmeler, yüksek kara sahip olsalar bile yeterli nakit yaratamazlarsa finansal sıkıntıyla karşı karşıya kalabilirler.

İşletmelerin gereksinim duyacakları bu nakdi esas işletme faaliyetlerinden yaratması önemli bir performans göstergesi olarak kabul edilmektedir. Bunların dışında işletmeler yatırım ve finansman faaliyetlerinden de nakit girişi elde edebilirler. Bu açıdan bakıldığında işletmelerin hangi faaliyetlerinden nakit sağladığı ve bu nakdi hangi faaliyetlere kullandığı bilgisini sunan nakit akış tablolarının finansal analiz, finansal planlama ve karar alma süreçlerinde önemi gittikçe artmaktadır. Bu bağlamda TMS / TFRS'lerin uygulama alanının genişlemesiyle birlikte, risk ve belirsizliğin yüksek olduğu turizm sektöründeki konaklama işletmelerinin yöneticilerinin nakit akış tablosuna, bu işletmelerin finansal durumunun belirlenmesinde kullanım düzeyinin artacağı düşünülmektedir.

$\mathrm{Bu}$ çalışmada halka açık konaklama işletmelerinin nakit akış performansları "Nakit Akışlarının Sağlandığı Faaliyetler Yöntemine" göre uluslararası olarak karşılaştırmalı analiz edilmeye çalışılmıştır. Bu kapsamda Amerika kıtasında yer alan 5 ülke borsasında işlem gören 25, Avrupa kıtasında yer alan 13 ülke borsasında işlem gören 51 ve Asya-Pasifik kıtasında yer alan 16 ülke borsasında işlem gören 131 olmak üzere toplamda 207 konaklama işletmesi analize dahil edilmiştir. Bu kapsamda halka 
açık 207 konaklama işletmesinin 2013-2015 yıllarını kapsayan nakit akış tablolarının üç ana kaleminin (işletme, yatırım ve finansman faaliyetleri) yönü (pozitif veya negatif) "Nakit Akışlarının Sağlandığı Faaliyetler Yöntemi" ne göre incelenmiştir. Bu inceleme yıl ve kıta bazında gerçekleştirilmiştir.

Analizde öne çıkan sonuçlardan ilki, incelenen halka açık konaklama işletmelerinin nakit akış profilleri, kıta temelinde; Model $2(+,-,-)$ başarılı işletme, Model $4(+,-,+)$ büyüyen işletme, Model $3(+,+,-)$ gerileyen veya yeniden yapılanan işletme olarak sıralanmasıdır. Diğer bir ifadeyle analiz sürecinde Amerika, Avrupa ve AsyaPasifik Kıtalarında analize dahil edilen halka açık konaklama işletmelerinin nakit akış profillerinin ortalamada ağırlıklı olarak en fazla Model $2(+,-,-)$, daha sonra Model $4(+,-$ $,+)$ ve üçüncü olarak da Model $3(+,+,-)$ işletme profillerinde olduğu gözlemlenmiştir. Türkiye'deki halka açık konaklama işletmelerinin de analiz döneminde nakit akış profillerinin benzerlik göstererek en fazla Model $2(+,-,-)$, ikinci olarak Model $4(+,-,+)$ ve üçüncü olarak da Model $3(+,+,-)$ işletme profillerinde olduğu gözlemlenmiştir. Bu bağlamda genel olarak nakit akış profilleri açısından 2013-2015 yılları arasında halka açık konaklama işletmelerinde Model 2 profilinin yaygın olarak görüldüğü ve başarılı işletmeler oldukları söylenebilir. İkinci olarak Model 4'e giren nakit akış profilinin yaygın olduğu ve bu işletmelerin büyüme eğilimi içerisinde olduğu kabul edilebilir. Nakit akışı profili sıralamasında Model 3 ise üçüncü sıradadır. Bu profile sahip işletmeler, faaliyet ve yatırım faaliyetlerinden nakit akışları pozitif, finansman faaliyetlerinden nakit akışları ise negatif düzeyde görülmektedir. Esas faaliyetlerden elde edilen gelir ve aktif satışından (duran varlık) elde edilen nakit ile borçlar karşılanıyor olabilir. Diğer bir ifadeyle bu profildeki işletmeler gerileyen veya yeniden yapılanan işletme olarak tanımlanmaktadır. Bu profile sahip işletmeler gerileyen veya yeniden yapılanan işletme olarak tanımlanmaktadır. Dolayısıyla farklı kıtalarda yer alsa da halka açık konaklama işletmelerinin benzer bir performansa sahip oldukları ve başarılı, büyüyen veya gerileyen/yeniden yapılanan işletmeler oldukları söylenebilir. Ayrıca Türkiye'deki halka açık konaklama işletmelerinin de hem içinde bulunduğu Avrupa Kıtası'na hem de Amerika ile Asya-Pasifik kıtalarındaki konaklama işletmeleriyle benzer bir nakit akış performansı sergilediği söylenebilir.

Analizde öne çıkan sonuçlardan ikincisi ise analiz sürecinde kıta temelinde nakit akış profili en fazla Model $2(+,-,-)$ başarılı işletme profiline giren konaklama işletmesinin Asya-Pasifik Kıtası'nda yer aldığı ve bu kıtayı Avrupa ve Amerika Kıtalarının izlediği yönündedir. Analiz sürecinde kıta temelinde nakit akış profili en fazla Model $4(+,-,+)$ büyüyen işletme profiline giren konaklama işletmesinin Avrupa Kıtası'nda yer aldığı ve bu kıtayı Asya-Pasifik ve Amerika Kıtalarının izlediği belirlenmiştir. Yine analiz sürecinde kıta temelinde nakit akış profili en fazla Model 3 $(+,+,-)$ gerileyen veya yeniden yapılanan işletme profiline giren konaklama işletmesinin Amerika Kıtası'nda yer aldığı ve bu kıtayı Avrupa ve Asya-Pasifik Kıtalarının izlediği belirlenmiştir. Bu bağlamda nakit akışlarının yönü açısından en fazla başarılı konaklama işletmesinin Asya-Pasifik ülkelerinde, en fazla büyüyen konaklama işletmesinin Avrupa ülkelerinde ve en fazla gerileyen veya yeniden yapılanan konaklama işletmesinin ise Amerika kıtasındaki ülkelerde olduğunu söylemek mümkündür. Ayrıca Türkiye açısından Model 2'ye giren işletme sayısının toplam içindeki üç yıllık ortalamasının da Avrupa kıtasındaki sonuçlara yakın olduğu belirlenmiştir. Buna karşın Avrupa'ya göre Türkiye'den daha fazla konaklama işletmesinin Model $3(+,+,-)$ gerileyen veya yeniden yapılanan işletme profiline girdiği saptanmıştır.

Analizde öne çıkan sonuçlardan üçüncüsü ise analiz sürecinde Model $1(+,+,+)$, Model $5(-,+,+)$, Model $7(-,+,-)$ ve Model $8(-,-,-)$ 'in nadir olarak gerçekleştiği, Model 
6'nın $(-,-,+)$ ise çeşitli durumlarda azda olsa ortaya çıktığı görülmektedir. Yıllar itibariyle her ne kadar, Model $2(+,-,-)$ başarılı işletme, Model $4(+,-,+)$ büyüyen işletme ve Model $3(+,+,-)$ gerileyen veya yeniden yapılanan işletme nakit akış profilleri ön planda ise de, sıralamada, Model $6(+,+,-)$ hızlı büyüyen genç işletme profili dördüncü sıradadır. Türkiye açısından bakıldığında da benzer sonuçlara ulaşılmıştır.

Analizde öne çıkan sonuçlardan dördüncüsü ise analiz sürecinde halka açık konaklama işletmelerinin büyük çoğunluğunun işletme faaliyetlerinden pozitif, yatırım faaliyetlerinden negatif nakit akışı sağladığı belirlenmiştir. Diğer taraftan konaklama işletmelerinin çoğunun finansman faaliyetleri açısından negatif nakit akışına sahip işletmeler olduğu saptanmıştır.

Elde edilen sonuçlar, farklı sektörlere yönelik olarak gerçekleştirilse de Gup vd. (1993), Bruwer ve Hamman (2005), Karğın ve Aktaş (2011), Aktaş ve diğ. (2012) ve Orhan ve Başar (2015) 'ın vardığı sonuçlarla uyumludur. Model 2 (+,-,-) nakit akış profili bütün çalışmalarda da, bu çalışmada olduğu gibi ilk sıradadır. Model $4(+,-,+)$, Model $3(+,+,-)$ ve Model $6(-,-,+)$ nakit akış profilleri sıralaması çok az farklılar gösterebilmekte ve söz konusu çalışmalarda da önemli oranlarda sıralamaya girmektedirler. Bir diğer benzer sonuç, nadir rastlanan nakit akış profilleri ile ilgilidir. Yukarıda adı geçen çalışmalarda da Model $1(+,+,+)$, Model $5(-,+,+)$, Model $7(-,+,-)$ ve Model 8 (-,-,-) nakit akış profillerine sahip işletme sayısı nadir olarak belirlenmiştir.

Nakit Akışlarının Sağlandığı Faaliyetler Yöntemi, uygulaması ve yorumu kolay olan bir analiz yöntemidir. Bu bağlamda işletme performansının analizinde uygulanan diğer finansal analiz tekniklerinin yanında tamamlayıcı olarak kullanılabilir. Konaklama işletmelerinin elde etmiş oldukları nakit akış özelliklerine göre sınıflandırılması, bu işletmelerin finansal ve operasyonel durumlarının analizi açısından faydalı bir araç olarak ortaya çıkmaktadır. Bu bağlamda gelecekteki çalışmalarda yeni ilave verilerle birlikte söz konusu nakit akış özelliklerindeki değişimler ve eğilimler de incelenebilir.

\section{Kaynakça}

Aktaş, R., Karğın, S., Karğın, M. (2012), "Nakit Akışlarının Sağlandığı Faaliyetler Yöntemi ile İşletmelerin Nakit Akış Profillerinin İncelenmesi", Muhasebe ve Finansman Dergisi, 56, ss. 110-118.

Bruwer, S. ve Hamman, W.D. (2005), "Cash Flow Patterns in Listed South African Industrial Companies", Meditari Accountancy Research, 13(1), ss.1-17.

Elmas, B. (2015), Finansal Tablolar Analizi: TMS/TMRS'ye Göre Kaleme Alınmış Piyasadan Gerçek Örnekler Üzerinden Analizler, Ankara: Nobel Akademik Yayıncılık Eğitim Danışmanlık.

Financial Times (2016), "Market Datas", http://markets.ft.com/data/equities/results (21.09.2016).

Gup, B.E., Samson, W.D., Dugan, M.T., Kim, M.J., Jittrapanun, T. (1993), “An Analysis Of Patterns From The Statement Of Cash Flows", Financial Practice and Education, 3(2), ss. 73-79.

Karğın, M. ve Aktaş, R. (2011), "Türkiye Muhasebe Standartlarına Gore Raporlanmış Nakit Akış Tablosu ve Analizi”, Muhasebe-Finansman Dergisi, 52, ss. 1-23.

Kordestani, G., Biglari, V., Bakhtiari, M. (2011), "Ability of Combinations of Cash Flow Components to Predict Financial Distress", Business:Theory and Practice, 12(3), ss. 277-285.

Orhan, A. ve Başar, B. (2015), "İ̧̧letmelerde Nakit Akış Profilleri Ve Analizi: Bist 100 İşletmeleri Üzerine Bir Uygulama", Muhasebe ve Vergi Uygulamaları Dergisi, 8(2), ss.107-121. 
Shamsudin, A. ve Kamaluddin, A. (2015), "Impending Bankruptcy: Examining Cash Flow Pattern of Distress and Healthy Firms" Procedia Economics and Finance, 31, ss. 766-774.

Şamiloğlu, F. ve Akgün, A. İ. (2015), Türkiye Finansal Raporlama Standartlarına Uygun Finansal Tablolar Analizi, Bursa: Ekin Basım Yayın Dağıtım.

Toroslu, V. ve Durmuş, N.C. (2016), Finansal Tablolar Analizi: Kavramlar-Analiz Teknikleri, Ankara: Seçkin Kitapevi.

Türkiye Muhasebe Standardı - TMS 7, (2016), Nakit Akış Tabloları, http://kgk.gov.tr/contents/files/TMS7.pdf . (22.09.2016).

Uyar, A. (2015), Kurumsal Raporlamanın Gelişimi ve Güncel Yaklaşımlar, Ankara: Gazi Kitapevi. 